\title{
EFEKTIFITAS REAL MICROTEACHING PADA PROGRAM PPL I (MICROTEACHING) DI PROGRAM STUDI PENDIDIKAN SOSIOLOGI FISE UNY
}

\author{
V. Indah Sri Pinasti ${ }^{1}$
}

\begin{abstract}
Abstrak
Penelitian ini pada dasarnya berpijak dari dan bertujuan untuk menjawab permasalahan bagaimanakah meningkatkan efektifitas waktu dan tempat dalam pelaksanaan Real Microteaching, bagaimana pemilihan materi yang tepat dan untuk meningkatkan kemampuan mengajar bagi mahasiswa calon guru.

Penelitian ini menggunakan metode kualitatif. Metode ini dipilih dengan pertimbangan bahwa penelitian ini dilaksanakan melalui pengamatan dan wawancara yang mendalam terhadap beberapa mahasiswa yang mengikuti praktik pengajaran mikro dengan model real microteaching. Lokasi penelitian adalah di program studi Pendidikan Sosiologi, FISE, UNY pada tahun ajaran 2008. Adapun teknik pengumpulan datanya dilakukan dengan observasi langsung, kemudian dilengkapi dengan wawancara yang mendalam terhadap responden dan dilengkapi dengan dokumen pelaksanaan real microteaching berupa catatan maupun berupa rekaman audio visual.

Hasil penelitian menunjukkan bahwa dari aspek waktu dan tempat pelaksanaan, real microteaching memerlukan waktu yang lebih lama dan tempat pelaksanaan yang memadai terkait dengan kehadiran siswa (real) ke kampus. Dilihat dari aspek materi yang disampaikan bisa lebih baik karena menyesuaikan materi yang sedang dan akan diajarkan di sekolah. Dilihat dari aspek siswa yang dijadikan model, terlihat antusias dalam mengikuti kegiatan real microteaching, siswa lebih alami melakukan kegiatan pembelajaran karena kehadiran mahasiswa praktikan dan nuansa baru pembelajaran dengan multimedia yang lebih menarik. Dilihat dari segi praktikan yang kurang siap, ternyata dengan kegiatan real microteaching mahasiswa praktikan justru menjadi lebih siap karena harus menghadapi situasi alami disek3lah meskipun dalam keadaan yang mikro baik siswanya maupun materinya. Dilihat dari aspek supervisor yang ada dalam ruangan, ternyata kehadirannya menyebabkan suasana tampak lebih tegang, kurang alami berbeda dengan situasi pembelajaran mikro yang dilakukan di dalam Laboratorium Mikro Teaching yang memang sudah dipersiapkan tempat khusus bagi supervisor sehingga kehadirannya tidak mengganggu pelaksanaan real microteaching.
\end{abstract}

Kata Kunci : Efektifitas, Real Microteaching, Pendidikan Sosiologi.

\footnotetext{
${ }^{1}$ Penulis adalah pengajar pada prodi Pendidikan Sosiologi FISE UNY
} 


\section{A. Pendahuluan}

Pengajaran mikro (PPLI) merupakan pelatihan tahap awal dalam pembentukan kompetensi mengajar melalui pengaktualisasian dasar mengajar. Pada dasarnya pengajaran mikro merupakan suatu metode pembelajaran atas dasar perfoma yang tekniknya dilakukan dengan cara melatihkan komponenkomponen kompetensi dasar mengajar (teaching skill) dalam proses pembelajaran sehingga calon guru benar-benar mampu menguasai setiap komponen satu persatu atau beberapa komponen secara terpadu dalam situasi pembelajaran yang disederhanakan atau dikecilkan dilihat dari aspek komponen pembelajaran, materi peserta didik, maupun waktu (Waskito, $1987: 1$ ).

Praktik di sekolah adalah praktik mengajar bersifat aplikatif dan terpadu dari seluruh pengalaman belajar sebelumnya. Untuk menyiapkan mahasiswa agar memiliki kemampuan keguruan, sehingga dengan mengemban tugas dan tanggung jawab penuh sebagai guru atau tenaga kependidikan.

Praktik di sekolah bertujuan untuk melatih mahasiswa agar memiliki pengalaman teraktual tentang proses pembelajaran di sekolah, selanjutnya dapat dipakai untuk bekal mengembangkan diri sebagai guru atau tenaga kependidikan yang professional dan memiliki nilai, sikap, pengetahuan serta ketrampilan yang diperlukan dalam profesinya.

Dalam pelaksanaan pengajaran mikro mencakup kegiatan orientasi, observasi pembelajaran di sekolah atau di lembaga yang akan dipakai, serta praktik mengajar dengan model peer teaching karena masih terbatasnya pengadaan atau rekrutmen siswa (peserta didik), perangkat, dan peralatan pendukung pengajaran mikro.
Dalam pengajaran mikro, mahasiswa dapat berlatih kompetensikompetensi dasar mengajar secara terbatas pada aspek kompetensi yang belum dikuasai atau berlatih secara terpadu dari beberapa kompetensi dasar mengajar, namun masih tetap terbatas dari aspek kompetensi mengajar, materi, peserta didik, maupun waktu. Praktik mengajar dilakukan sampai mahasiswa yang bersangkutan menguasai kompetensi dasar mengajar secara memadai sebagai prasyarat praktik pembelajaran di sekolah atau lembaga kependidikan.

Dalam pengertian lain, terkait dengan standar kompetensi mengajar adalah memberi pelajaran pada siswa yang sedang belajar (pembelajar) (Handaniwati dkk, 2003 : 8). Dalam hal ini pengajar memberdayakan diri sendiri dan pembelajar sehingga proses pembelajaran dapat berlangsung. Pembelajar diharapkan memiliki kompetensi yang diajarkan. Pembelajar diposisikan sebagai subyek belajar, sedangkan pengajar (guru) . sebagai fasilitator. Hal ini sesuai dengan prinsip pembelajaran berbasis kompetensi. Guru membelajarkan dan memberdayakan pembelajar sehingga pembelajar memiliki kompetensi tertentu.

Standar kompetensi mata kuliah pengajaran mikro adalah tuntutan minimal kompetensi dasar mengajar yang ditunjukkan oleh kemampuan untuk mendemonstrasikan atau mengaplikasikan kompetensi tersebut dalam proses belajar mengajar berskala kecil.

Pelaksanaan PPL I (microteaching) pada tahun yang lalu dan pada tahun-tahun berikutnya di F1SE, sebelum mahasiswa terjun ke lapangan (praktek mengajar di sekolah), diawali dengan pelaksanaan real microteaching (mendatangkan siswa) dari sekolah untuk dijadikan siswa bagi mahasiswa praktikan (calon guru). Namun berdasarkan 
pengamatan secara sepintas, program real microteaching ini banyak .sekali menimbulkan fenomena yang menarik untuk diteliti lebih lanjut, terutama pada segi efektifitasnya, yang meliputi : waktu, materi, siswa, praktikan dan supervisor, serta dampaknya bagi mahasiswa praktikan.

\section{B. Hakekat Pembelajaran Sosiologi.}

Ada dua pengertian dasar mengenai sosiologi yaitu sebagai ilmu dan sebagai metode. Sosiologi sebagai ilmu merupakan kumpulan pengetahuan tentang masyarakat dan kebudayaan yang disusun secara sistematis berdasarkan analisis berfikir logis. Sedangkan sosiologis sebagai metode adalah cara berfikir untuk mengungkapkan realitas sosial yang ada dalam masyarakat dengan prosedur dan teori yang dapat dipertangungjawabkan secara ilmiah. Pembelajaran pada dasarnya merupakan proses untuk mencapai tujuan, dalam hal ini lebih menekankan pada proses mencari dan menemukan pengetahuan melalui kemampuan siswa itu sendiri. Pembelajaran Sosiologi dimaksudkan untuk mengembangkan kemampuan pemahaman fenomena kehidupan sehari-hari.

\section{Pengertian Efektifitas.}

Kamus Besar Bahasa Indonesia (1990 : 219) menerangkan bahwa efektif berarti ada efeknya, manjur dan mujarab serta berhasil guna. Selain itu menurut Abdul Qohar (1989 : 65) menuliskan bahwa efektif berarti tepat pada sasaran, mempunyai akibat yang tepat. Keefektifan proses pembelajaran berkenaan dengan jalan, upaya, teknik dan strategi yang digunakan dalam mencapai tujuan secara optimal, tepat dan cepat ( Nana Sudjana, 1990 : 50). Faktor yang mempengaruhi efektivitas pembelajaran antara lain kemampuan dalam menggunakan metode, media dan strategi pembelajaran yang digunakan. Kaitannya dengan kegiatan real microteaching, efektifitas dipengaruhi oleh faktor tujuan, peserta didik, situasi fasilitas dan kesiapan mahasiswa praktikan itu sendiri. Dapat dikatakan bahwa efektifitas pelaksanaan real microteaching merupakan pencerminan untuk mencapai tujuan pelaksanaan real microteaching yang tepat pada sasarannya sesuai dengan tujuan yang hendak dicapai.

\section{Pengertian Real Mikroteaching.}

Pengajaran mikro merupakan pelatihan tahap awal untuk mengaktualisasikan kompetensi dasar mengajar. Pengajaran mikro mencakup kegiatan orientasi dan observasi proses pembelajaran serta praktik mengajar terbatas dengan model peer teaching. Istilah Real Microteaching di sini adalah pelaksanaan pengajaran mikro seperti biasanya namun ada perbedaan dari segi prakteknya. Bila selama ini pembelajaran mikro menggunakan peer teaching atau teman sejawat, maka dalam real microteaching digunakan real siswa yang sebenarnya. Siswa didatangkan dari sekolah ke kampus, dalam rangka memberi nuansa alami pembelajaran bagi mahasiswa praktikan.

Pengajaran mikro yang dilakukan di Pendidikan Sosiologi adalah menggunakan model baru pengajaran mikro yaitu model real microteaching, dengan menggunakan siswa yang diambil dari salah satu sekolah. Tentu saja hal ini menjadi sangat menarik, karena terlihat nyata adanya perubahan suasana dan nuansa dalam praktik pengajaran mikro. Inilah yang menjadi tantangan yang hares dihadapi oleh mahasiswa praktikan sebelum nantinya terjun ke sekolah, yang tentu saja situasi, kondisi dan lingkungannya sangat berbeda dengan lingkungan kampus.

Dalam pengajaran mikro, mahasiswa dapat mengajar secara 
bagian-bagian atau secara utuh untuk beberapa aspek kompetensi yang belum dikuasai. Praktik dapat dilakukan sampai mahasiswa yang bersangkutan menguasai kompetensi secara memadai sebagai pra-syarat PPL (Praktik Pengalaman Lapangan) di sekolah.

Secara umum, pengajaran mikro bertujuan untuk membentuk dan mengembangkan kompetensi dasar mengajar sebagai bekal praktik mengajar (real microteaching) di sekolah / lembaga pendidikan. Secara khusus, tujuan pengajaran mikro adalah sebagai berikut :
a. Membentuk
dan meningkatkan kompetensi dasar mengajar terbatas.

b. Membentuk dan meningkatkan kompetensi dasar mengajar terpadu dan utuh untuk beberapa kompetensi dasar mengajar.

Pelaksanaan pengajaran mikro diadakan di kampus UNY dibimbing oleh dosen pembimbing dalam bentuk peer teaching, yaitu mahasiswa melakukan praktik mengajar di hadapan temannya sendiri, kemudian dilanjutkan dengan real microteaching dengan siswa dari sekolah dengan jumlah yang terbatas (8-10 siswa).

Praktik pengajaran mikro meliputi : (1) latihan kompetensi dasar mengajar terbatas, dan (2) latihan kompetensi dasar mengajar secara terpadu dan utuh. Banyaknya latihan dan praktik bagi setiap mahasiswa adalah 8 kali dengan memperhatikan tingkat pencapaian kompetensi yang dikuasai mahasiswa.

Pengajaran mikro adalah model sebuah pengajaran yang di mikrokan dan dibatasi dalam aspek-aspek : a) jumlah siswa antara 10-15 orang, b)materi pelajaran, c) waktu penyajian antara 10-15 menit, dan d) ketrampilan atau kemampuan yang dilatihkan.

Kompetensi dasar mengajar dalam pengajaran mikro adalah kemampuan minimal yang harus dicapai mahasiswa terhadap pengajaran mikro. Kompetensi dasar dan indikator dalam pengajaran mikro adalah sebagai berikut :

\begin{tabular}{|c|c|}
\hline Kompetensi Dasar & Indikator \\
\hline $\begin{array}{l}\text { 1. Menyebutkan dasar- } \\
\text { dasar pengajaran mikro }\end{array}$ & $\begin{array}{l}\text { a. Mendiskripsikan makna pengajaran } \\
\text { mikro. } \\
\text { b. Menganalisis prinsip-prinsip pengajaran } \\
\text { mikro. }\end{array}$ \\
\hline $\begin{array}{l}\text { 2. Menyusun rencana } \\
\text { pembelajaran. }\end{array}$ & $\begin{array}{l}\text { a. Menyebutkan komponen-komponen } \\
\text { rencana pembelajaran mikro (RP) dalam } \\
\text { pengajaran mikro. } \\
\text { b. Menyusun komponen-komponen } \\
\text { tersebut menjadi RP. }\end{array}$ \\
\hline 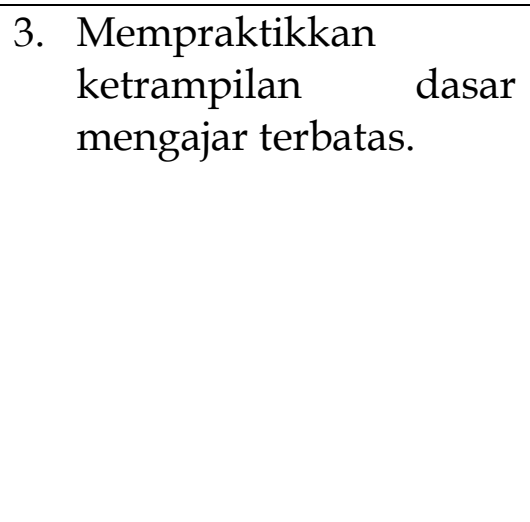 & $\begin{array}{l}\text { a. Mendemonstrasikan } \\
\text { ketrampilan mengajar terutama yang } \\
\text { meliputi : membuka dan menutup } \\
\text { pelajaran, menerangkan dan menjelaskan } \\
\text { materi, memberikan penguatan, } \\
\text { menggunakan media dan alat } \\
\text { pembelajaran, menyusun skenario. } \\
\text { pembelajaran, mengadakan variasi, } \\
\text { membimbing diskusi, mengelola kelas, } \\
\text { teknik bertanya dan teknik evaluasi. }\end{array}$ \\
\hline $\begin{array}{l}\text { 4. Mempraktikkan } \\
\text { ketrampilan dasar } \\
\text { mengajar terpadu }\end{array}$ & $\begin{array}{l}\text { a. Mendemonstrasikan beberapa } \\
\text { ketrampilan mengajar terpadu yang } \\
\text { meliputi merumuskan mengajar terpadu. }\end{array}$ \\
\hline
\end{tabular}




\begin{tabular}{|c|c|}
\hline & $\begin{array}{l}\text { kompetensi dasar, menentukan dan } \\
\text { menyusun materi pokok dan uraiannya, } \\
\text { mengintegrasikan pengalaman belajar } \\
\text { (tatap muka dan berwawasan kontekstual } \\
\text { teaching and learning atau CTL), } \\
\text { mengintegrasikan kecakapan hidup pada } \\
\text { materi pembelajaran, menyusun dan } \\
\text { merumuskan indikator, menyusun dan } \\
\text { merumuskan slat penilaian, menyusun } \\
\text { dan merencanakan interaksi } \\
\text { pembelajaran dan skenario pembelajaran. } \\
\text { b. Mempraktikkan ketrampilan mengajar } \\
\text { terpadu dalam bentuk simulasi } \\
\text { pengajaran mikro. }\end{array}$ \\
\hline $\begin{array}{l}\text { 5. Mengevaluasi } \\
\text { praktik pengajaran } \\
\text { mikro }\end{array}$ & $\begin{array}{l}\text { a. Melakukan observasi kegiatan praktik } \\
\text { simulasi pengajaran mikro. } \\
\text { b. Menganalisis hasil pengajaran mikro. }\end{array}$ \\
\hline
\end{tabular}

\section{E. Metode Penelitian}

Penelitian ini menggunakan metode kualitatif. Metode ini dipilih dengan pertimbangan bahwa penelitian ini akan dilaksanakan melalui pengamatan dan wawancara terhadap beberapa mahasiswa yang mengikuti praktik pengajaran mikro real microteaching.

Penelitian dilakukan di Jurusan Pendidikan Sejarah FISE UNY, khususnya program studi Pendidikan Sosiologi. Objek atau informan penelitian adalah mahasiswa semester VI yang dipilih berdasarkan mahasiswa yang mengambil praktik pengajaran mikro.

\section{F. Proses Pelaksanaan Real Microteaching.}

1. Pembekalan praktik Pengajaran Mikro pada mahasiswa. Mahasiswa

pendidikan

Sosiologi yang akan mengambil mata kuliah PPL 1 atau Pengajaran Mikro diwajibkan mengikuti pembekalan secara klasikal. Materi pembekalan praktik pengajaran mikro meliputi : konsep dasar pengajaran mikro, mekanisme pengajaran, observasi proses pembelajaran mikro dan kondisi sekolah, kompetensi guru, kemampuan dasar mengajar, rencana pembelajaran silabus dan sistem penilaian dalam pengajaran mikro.

2. Pelaksanaan praktik Pengajaran Mikro.

Pada tahun akademik 2008-2009 mahasiswa pendidikan sosiologi yang melaksanakan praktik pengajaran mikro teaching sejumlah 60 mahasiswa. Mahasiswa dalam satu minggu mendapat kesempatan satu kali untuk melakukan kegiatan praktik pengajaran mikro di laboratorium Micro Teaching F1SE UNY. Untuk melengkapi standar minimal seperti yang ditetapkan UPPL maka pembelajaran mikro juga dilakukan ruang kuliah biasa di luar jadwal microteaching di laboratorium.

Dosen pembimbing yang terlibat dalam pengajaran mikro adalah 10 orang. Seluruh dosen pembimbing telah melakukan tugasnya dengan baik sesuai dengan jadwal kegiatan praktikum. Berdasarkan realisasi pelaksanaan pengajaran mikro yang dibimbing oleh dosen pembimbing yang sekaligus sebagai supervisor dapat dikatakan pengajaran mikro di pendidikan sosiologi berjalan dengan lancar. Hasil kelulusan yang dicapai dalam 
pelaksanaan praktik pengajaran mikro untuk program studi pendidikan sosiologi tahun 2008 ini mencapai 100 persen.

2. Rekaman pelaksanaan pengajaran mikro.

Pelaksanaan pengajaran mikro teaching yang berlangsung di laboratorium micro Belching selalu direkam dengan peralatan kamera yang memang telah terpasang secara permanen Masing-masing kelompok direkam minimal 4 kali selama pelaksanaan pengajaran mikro. Hasil rekaman ini dipakai oleh pembimbing untuk menunjukkan : kesalahankesalahan praktikan, menunjukkan kemajuan yang telah dicapai dan evaluasi untuk perbaikan praktikan pada praktik selanjutnya. Rekaman ini juga menjadi bahan analisis bagi peneliti. Rekaman dapat dicopy oleh mahasiswa praktikan untuk feedback tentang kelemahan-kelemahan yang ada pada masing-masing praktikan.

Hasil analisis terhadap rekaman yang meliputi sikap, ketrampilan, mental dan penguasaan materi mahasiswa dirasakan sangat bermanfaat bagi mahasiswa. Hal ini terjadi karena mahasiswa merasa bahwa masukan serta saran dari supervisor sangat riil sesuai dengan kondisi yang terjadi dalam rekaman. Dengan demikian mahasiswa merasa percaya, mantap dan senang, serta menyadari banyak sikap dan perilaku yang tidak mereka sadari telah terjadi selama praktik.

3. Siswa sekolah Menengah sebagai Real Student.

Untuk keperluan praktik pengajaran mikro dengan model Real Microteaching, maka FISE UNY mendatangkan siswa dari sekolah menengah di lingkungan dinas pendidikan provinsi DIY sebagai mitra kerja. Untuk program studi Pendidikan Sosiologi khususnya siswa yang didatangkan sebagai sekolah mitra adalah dari SMA 9 Yogyakarta.
Jumlah siswa yang didatangkan adalah 40 siswa dari kelas 10, Siswa dibagi dalam 4 kelompok pengajaran mikro sehingga masing-masing kelompok berjumlah 10 orang. Karena keberadaan laboratorium Micro Teaching yang hanya 2 buah, maka pelaksanaan real microteaching juga menggunakan ruang kuliah sebagai tempat kegiatannya, namun demikian masing-masing kelompok pasti menggunakan laboratorium sehingga semua kelompok juga melakukan rekaman audio visual di laboratorium.

Siswa dari Sekolah yang didatangkan ke kampus juga didampingi oleh dua orang guru pembimbing yang sekaligus sebagai supervisor kegiatan real microteaching bersama roach pembimbing yang ada di kampus. Kehadiran guru pembimbing ke kampus dalam rangka lebih mengefektifkan proses pengajaran mikro, serta dapat memberikan arahan pada mahasiswa kondisi real di sekolah ketika nanti hams melakukan praktik pengalaman lapangan.

\section{G. Kinerja Praktik Pengajaran Mikro dengan model Real Microteaching.} Untuk menilai kinerja praktik pengajaran mikro dengan menggunakan model Kcal microteaching, dilakukan dengan membandingkan hasil penilaian terhadap praktik pengajaran mikro. Lembar penilaian menggunakan standar penilaian dari UPPL baik mink penyusunan RPP maupun pelaksanaan pembelajaran mikro. Kegiatan praktik pengajaran mikro mahasiswa pendidikan sosiologi terbagi dalam dua model kegiatan. Model pertama, yaitu pengajaran mikro menggunakan teman sejawat sebagai audien yang merupakan kegiatan pengajaran mikro standar yang dilakukan oleh semua mahasiswa UNY. Model kedua adalah praktik pengajaran mikro dengan menggunakan siswa sekolah 
menengah sebagai audien yang kami sebut dengan Real Microteaching.

Mengingat keterbatasan waktu, biaya dan fasilitas praktik pengajaran mikro, maka selama 8 (delapan) kali pelaksanaan praktik pada semester genap 2008/2009, mahasiswa praktik 7 (tujuh) kali dengan model pengajaran mikro standar UPPL dan 1(satu) kali dengan menggunakan Real Microteaching. Selama melakukan kegiatan Real microteaching dilakukan penilaian dengan menggunakan lembar penilaian dari UPPL. Setelah selesai dengan kegiatan praktik dengan model Real Microteaching, kemudian beberapa mahasiswa diwawancarai tentang pelaksanaan kegiatan Real Microteaching.

Penilaian pengajaran mikro dengan model standar UPPL dan dengan model Real microteaching kemudian dibandingkan. Rata-rata untuk nilai Mikro Teaching dengan model standar adalah 80,73 sedangkan yang menggunakan Real Microteaching adalah 84,2 (data lengkap lihat lampiran). Data menunjukkan bahwa skor rata-rata pengajaran Mikro dengan Real Microteaching lebih tinggi dibandingkan dengan skor rata-rata model praktek standar UPPL dengan kenaikan rata-rata nilai/skor sebesar
3,47. Hasil komputasi menunjukkan bahwa koefisien $\quad t=2.92737$ ini memiliki makna sangat signifikan, karena , $t=2,92737$ lebih besar terhadap harga kritis $t=2,660$ pada taraf signifikansi $1 \%$. Kenaikan nilairata diakibatkan oleh meningkatnya mutu persiapan dan bimbingan dosen pada saat mahasiswa akan melaksanakan praktik pengajaran mikro. Pada saat Real microteaching, mahasiswa melakukan persiapan jauh lebih intensif. Hal ini dilakukan untuk mengangkat harga diri jangan sampai mereka dipermalukan oleh siswa sekolah menengah di depan kelas. Di sinilah efek penting adanya Real Microteaching yang mendatangkan siswa sesungguhnya dari sekolah mitra. Hanya saja konsekuensinya adalah diperlukan biaya yang relatif mahal dan adanya kemitraan yang baik dengan sekolah.

\section{H. Kinerja Real Microteaching Berdasarkan data Kualitatif.}

Untuk mendukung validitas informasi, peneliti juga berupaya menjaring data kualitatif melalui angket yang diberikan kepada siswa sekolah menengah yang menjadi audien pada saat praktik Real Microteaching. Adapun hasil jawaban siswa sekolah dapat dilihat sebagai berikut :

Tabel 1 : Hasil Rekapitulasi Jawaban Siswa.

\begin{tabular}{|c|l|l|}
\hline No & $\begin{array}{l}\text { Aspek yang } \\
\text { Ditanyakan }\end{array}$ & $\begin{array}{l}\text { Jawaban Siswa } \\
\text { mahasiswa ramah terhadap } \\
\text { siswa. }\end{array}$ \\
\hline 1 & Ramah & $\begin{array}{l}\text { Lebih dari 50 \%, menjawab } \\
\text { mahasiswa berperilaku sopan. }\end{array}$ \\
\hline 2 & Berbicara Sopan & $\begin{array}{l}100 \% \text { siswa menyatakan } \\
\text { mahasiswa berpakaian sopan. }\end{array}$ \\
\hline 4 & $\begin{array}{l}\text { Merpakaian sopan } \\
\text { dalam pelajaran siswa }\end{array}$ & $\begin{array}{l}\text { Lebih 50 siswa mengatakan } \\
\text { mahasiswa sudah berusaha } \\
\text { melibatkan siswa }\end{array}$ \\
\hline 5 & $\begin{array}{l}\text { Menegur siswa yang } \\
\text { tidak memperhatikan } \\
\text { pelajaran }\end{array}$ & $\begin{array}{l}\text { Mayoritas siswa mengatakan } \\
\text { mahasiswa masih takut atau } \\
\text { grogi ketika akan menegur }\end{array}$ \\
\hline
\end{tabular}




\begin{tabular}{|c|l|l|}
\hline 6 & $\begin{array}{l}\text { Menguasai bahan } \\
\text { pelajaran }\end{array}$ & $\begin{array}{l}\text { Mayoritas siswa mengatakan } \\
\text { mahasiswa telah menguasai } \\
\text { bahan pelajaran }\end{array}$ \\
\hline 7 & $\begin{array}{l}\text { Jelas dalam menjawab } \\
\text { pertanyaan }\end{array}$ & $\begin{array}{l}\text { Mahasiswa rata-rata masih } \\
\text { ragu-ragu ketika harus } \\
\text { menjawab pertanyaan dari } \\
\text { siswa. }\end{array}$ \\
\hline 8 & $\begin{array}{l}\text { Jelas dalam } \\
\text { menerangkan } \\
\text { pelajaran }\end{array}$ & $\begin{array}{l}\text { Mayoritas siswa mengatakan } \\
\text { pemberian penjelasan tentang } \\
\text { mated yang diajarkan cukup } \\
\text { jelas. yan }\end{array}$ \\
\hline 9 & $\begin{array}{l}\text { Cara menarik dajar } \\
\text { Mayoritas siswa mengatakan, } \\
\text { pembelajaran cukup menarik } \\
\text { karena menggunakan banyak } \\
\text { media. }\end{array}$ \\
\hline 10 & $\begin{array}{l}\text { Perasaan dan kesan } \\
\text { Tertulis) } \\
\text { 1. Senang dengan } \\
\text { Kegiatan ini } \\
\text { 2. Menonton dan } \\
\text { kurang menarik }\end{array}$ & $\begin{array}{l}\text { Mayoritas menuliskan senang } \\
\text { dengan kegiatan ini, dan hanya } \\
\text { sedikit kurang dari 15 \% } \\
\text { menyatakan monoton dan } \\
\text { kurang menarik. }\end{array}$ \\
\hline
\end{tabular}

Berdasarkan tabel 1 kita dapat melihat bahwa secara kualitatif memang suasana pembelajaran dengan Real .Microteaching ini cukup bagus, menyenangkan dan menarik perhatian siswa. Hanya saja masih ada beberapa perilaku praktikan yang kurang seperti

a. Kemampuan penguasaan materi di luar yang diajarkan masih kurang, sehingga ketika ada pertanyaan di luar materi ajar, mahasiswa menjadi ragu-ragu dan agak grogi ketika memberikan jawaban.

b. Perhatian kurang fokus dalam berkomunikasi timbal balik dengan siswa.

c. Masih ada beberapa siswa yang dalam proses pembelajaran masih monoton dan kurang menarik karena tidak menggunakan media yang memadai.

Kondisi tersebut dia atas biasa terjadi bagi calon guru yang masih sangat sedikit pengalamannya. Oleh karena itu untuk meningkatkan ketrampilan dan kemampuan mengajar, praktikan harus serius dan intensif melakukan latihan-latihan berulangkali sehingga rasa percaya diri berkembang dan kemampuan mengelola kelas dan mengendalikan suasana kelas menjadi lebih baik. Berdasarkan bukti-bukti baik kuantitatif maupun kualitatif dapat disimpulkan bahwa pengajaran mikro dengan model Real Microteaching lebih efektif dibanding dengan pengajaran mikro model standar UPPL, Real Microteaching mampu meningkatkan kinerja mahasiswa calon guru untuk mencapai kompetensi mengajarnya yang meliputi kompetensi pedagogik, kepribadian, profesionalisme dan sosialnya.

\section{Simpulan}

Pelaksanaan Real Microteaching dengan melibatkan siswa dari sekolah menengah berdampak positif, efektifitas pelaksanaan Real Microteaching sangat positif, karena mahasiswa menjadi lebih siap, percaya diri dan mampu menguasai kelas.

Hasil skor penilaian sebelum mengikuti real microteaching dengan 
sesudah mengikuti real microteaching, menunjukkan peningkatan yang signifikan. Artinya mahasiswa lebih siap dan lebih memahami dalam proses pembelajaran di sekolah. Derajat ketrampilan mengajar jugs menunjukkan peningkatan, di banding dengan model sebelumnya (PPL I biasa).

Model real microteaching dapat meningkatkan kualitas proses pembelajaran terutama dalam hal mental, ketrampilan dan penguasaan materi. Hal ini terjadi karena mahasiswa praktikan merasa seperti menghadapi dimana dan kondisi riil di lapangan, berhadapan dengan siswa sekolah dengan berbagai permasalahan dan tingkah lakunya.

Berdasarkan analisis dapat diketahui perbedaan yaitu peningkatan hasil yang sangat signifikan. Secara kualitas juga menunjukkan hasil yang memadai sebagai sebuah, model pembelajaran untuk micro teaching. Sebagai implikasinya, maka ke depan model real microteaching ini dapat dilanjutkan di prodi Pendidikan Sosiologi, bahkan dapat ditingkatkan pelaksanaannya untuk tingkat fakultas bahkan kalau mungkin di tingkat universitas.

Dalam pelaksanaan memang muncul kendala di antaranya masalah ruang laboratorium mikro yang terbatas, waktu yang digunakan karena selama ini menggunakan hari libur yaitu hari sabtu, ketersediaan dana yang cukup, dan adanya kelemahan-kelemahan dalam sistem real microteaching yang harus diatasi. Namun apabila tujuannya adalah peningkatan mutu maka kendala tersebut tentunya akan dapat diatasi.

\section{Daftar Pustaka}

Burhan Bungin, 2003, Metodologi Penelitian Kualitatif : Aktualisasi Metodologis ke Arah Ragam Varian Kontemporer, Surabaya : raja Grafindo Persada.

Depdikbid, 1990, Kamus Besar Bahasa Indonesia, Jakarta : Balai Pustaka.

Hadari Nawawi, 1998, Metodologi Penelitian Bidang Sosial, Yogyakarta : Gajah Mada University Press.

Hardarniwati, Menuk Dkk. 2003, Kamus Pelajar, Jakarta : Pusat Bahasa.

Lexy J, Moleong, 2000, Metodologi Penelitian Kualitatif, Bandung : Remaja Rosda Karya.

Nana Sudjana, 1990, Media Pengajaran, Bandung : Sinar Baru.

Nasution, 2003, Metode Penelitian Naturalistik Kualitatif, Bandung : Tarsito.

Suwarno, 2005. Pengajaran Mikro, Yogyakarta : Tiara Wacana.

UNY, 2006. Panduan KKN-PPL, Yogyakarta : UNY.

UNY, 2005. Panduan Praktik Pengalaman Lapangan Program Pembentukan Kemampuan Mengajar (PPKM), Yogyakarta : F1P UNY. 